\title{
An investigation of antifungal susceptibilities of the Candida species isolates from blood cultures using the Sensititre YeastOne microdilution method
}

\section{Kan kültürlerinden izole edilen Candida türlerinin antifungal duyarlılıklarının Sensititre YeastOne mikrodilüisyon yöntemiyle araștırılması}

\author{
Raif KARAASLAN ${ }^{1}$, Esin AKTAŞ², Figen ORHAN ${ }^{3}$
}

\section{ABSTRACT}

Objective: Invasive fungal infections caused by Candida species have increased significantly. Therefore, rapid and correct identification to the species level and susceptibility testing have become important, especially in cases involving invasive infections. The Sensititre YeastOne method, based on the microdilution method, is an alternative to the Clinical and Laboratory Standards Institute (CLSI) reference method for antifungal susceptibility testing. Sensititre YeastOne is a method for determining the Minimal Inhibitory Concentration (MIC) values of Candida isolates with wells containing lyophilized antifungals. In our study, the aim was to determine the antifungal drug sensitivity of Candida isolates from blood cultures by using a Sensititre YeastOne colorimetric system.

Methods: Fifty candida isolates, each isolated from blood cultures of different patients in the Medical Microbiology Laboratory of Atatürk University Faculty of Medicine, were included in the study (16 Candida albicans, 14 Candida tropicalis, 8 Candida parapsilosis, 10 Candida glabrata, 2 Candida kefyr) and two quality control strain (Candida krusei ATCC 6258, Candida parapsilosis ATCC 22019) were included in the study. The

\section{ÖZET}

Amaç: Candida türlerinin neden olduğu invaziv fungal enfeksiyonlar önemli ölçüde artmıștır. Bu nedenle türlerin hızlı ve doğru tanımlanması ve duyarlılık testleri, özellikle fırsatçı enfeksiyonları içeren vakalarda oldukça önemlidir. Mikrodilüsyon esasına dayanan Sensititre YeastOne yöntemi, antifungal duyarlıık testi için Klinik ve Laboratuvar Standartları Enstitüsü referans yöntemine uygun bir alternatiftir. Sensititre YeastOne liyofilize halde antifungal içeren kuyucuklara sahip olup Candida izolatlarının Minimal İnhibitör Konsantrasyonu (MiK) değerlerinin belirlenmesi için geliștirilen bir yöntemdir. Çalıșmamızda kan kültürlerinden izole edilmiş Candida izolatlarının Sensititre YeastOne kolorimetrik sistem kullanılarak antifungal ilaç duyarlıı̆̆ının belirlenmesi amaçlanmıștır.

Yöntem: Çalıșmaya Atatürk Üniversitesi Tıp Fakültesi Tıbbi Mikrobiyoloji Laboratuvarı'nda her biri farklı hastalara ait kan kültürlerinden izole edilen 50 Candida izolatı (16 Candida albicans, 14 Candida tropicalis, 10 Candida glabrata, 8 Candida parapsilosis, 2 Candida kefyr) ve iki adet kalite kontrol suşu (Candida krusei ATCC 6258, Candida parapsilosis ATCC 22019) dahil edilmiştir. Türlerin antifungal duyarlılıkları, kolorimetrik

${ }^{1}$ Combat Air Force Command, Eskişehir

${ }^{2}$ Ankara Yildırım Beyazıt University, School of Medicine, Medical Microbiology Department, Ankara

${ }^{3}$ Atatürk University Health Services Vocational School, Erzurum

İletişim / Corresponding Author : Figen ORHAN

Atatürk Üniversitesi Sağlık Hizmetleri MYO Tibbi Laboratuvar Teknikleri Erzurum - Türkiye

E-posta / E-mail : figen.kayserili@hotmail.com

Geliş Tarihi / Received : 21.08.2019 Kabul Tarihi / Accepted : 15.08 .2020

DOI ID : 10.5505/TurkHijyen.2020.42650

Karaaslan R, Aktaș E, Orhan F. An investigation of antifungal susceptibilities of the Candida species isolates from blood cultures using the sensititre yeastone microdilution method. Turk Hij Den Biyol Derg, 2020; 77(3): 281-288 
antifungal susceptibilities of the species were tested by the microdilution method using a colorimetric method, Sensititre YeastOne (Trek Diagnostic Systems, USA).

Results: For all Candida species, MIC ranges were as follows: $0.12-2 \mu \mathrm{g} / \mathrm{ml}$ for amphotericin B; 0.12-256 $\mu \mathrm{g} / \mathrm{ml}$ for fluconazole; $0.008-8 \mu \mathrm{g} / \mathrm{ml}$ for voriconazole; 0.015-0.5 $\mu \mathrm{g} / \mathrm{ml}$ for caspofungin; $0.015-2 \mu \mathrm{g} / \mathrm{ml}$ for anidulafungin; $0.008-2 \mu \mathrm{g} / \mathrm{ml}$ for micafungin; 0.006-8 $\mu \mathrm{g} / \mathrm{ml}$ flucytosine; $0.008-8 \mu \mathrm{g} / \mathrm{ml}$ for posaconazole and $0.015-16 \mu \mathrm{g} / \mathrm{ml}$ for itraconazole.

Conclusion: Considering the low MIC values obtained, it was concluded that anidulafungin, micafungin, caspofungin, flucytosine, posaconazole, voriconazole, itraconazole and amphotericin B may be effective against Candida species and may be used as alternative drugs for the treatment of infections caused by fluconazole-resistant species.

Key Words: Antifungal, Microdilution method, Sensititre YeastOne, Candida bir sistem olan Sensititre YeastOne (Trek Diagnostic Systems, ABD) mikrodilüsyon yöntemi ile araștırılmıștır.

Bulgular: Çalıșma sonunda Candida izolatlarının tamamında MiK aralıkları; amfoterisin B için 0,12-2 $\mu \mathrm{g} / \mathrm{ml}$, flukonazol için $0,12-256 \mu \mathrm{g} / \mathrm{ml}$, vorikonazol için 0,008-8 $\mu \mathrm{g} / \mathrm{ml}$, kaspofungin için 0,015-0,5 $\mu \mathrm{g} / \mathrm{ml}$, anidulafungin için 0,015-2 $\mu \mathrm{g} / \mathrm{ml}$, mikafungin için 0,008 $2 \mu \mathrm{g} / \mathrm{ml}$, flusitozin için $0,006-8 \mu \mathrm{g} / \mathrm{ml}$, posakonazol için 0,008-8 $\mu \mathrm{g} / \mathrm{ml}$, itrakonazol için $0,015-16 \mu \mathrm{g} / \mathrm{ml}$ olarak belirlenmiștir.

Sonuç: Elde edilen düşük MiK değerleri göz önüne alındığında anidulafungin, mikafungin, kaspofungin, flusitozin, posakonazol, vorikonazol, itrakonazol ve amfoterisin B'nin Candida izolatlarına karșı etkin olabileceği ve flukonazole dirençli suşlarla oluşan enfeksiyonların tedavisinde alternatif ilaç olarak kullanılabilecekleri sonucuna varılmıștır.

Anahtar Kelimeler: Antifungal, Mikrodilüsyon yöntemi, Sensititre YeastOne, Candida

\section{INTRODUCTION}

Candida spp. stands in the fourth-place cause of among the most common agent in blood circulation infections. Currently, there has been a rapid increase observed in the incidence of fungal infections linked to the increase in patient number with suppressed immune systems, the increase in the use of large surgical interventions and more than one broadspectrum antibiotic, higher observation of patients with poor general status in intensive care units the popularity of artificial prosthesis use $(1,2)$.

Clinical and Laboratory Standards Institute (CLSI) and European Committee on Antimicrobial Susceptibility Testing (EUCAST), ensuring standardization of antifungal susceptibility tests, have developed standard microdilution methods for antifungal susceptibility tests. However, in practice there is a search for alternative methods that are easy to apply in routine laboratories due to these standard methods involving technical difficulties and subjective visual assessment (3). The Sensititre YeastOne method is an easy and rapid method to test 9 antifungal drugs at the same time and offers clinicians many antifungal treatment choices in the early period (4).

Our study aimed to test the susceptibilities of 50 Candida species isolated from blood cultures against anidulafungin, micafungin, caspofungin, flucytosine, posaconazole, voriconazole, itraconazole, fluconazole and amphotericin- $B$ using a microdilution-based colorimetric panel called the Sensititre YeastOne (TREK Diagnostic Systems, USA). 


\section{MATERIAL and METHOD}

Sensititre YeastOne is a microdilution method containing 9 lyophilized antifungal drugs, which aids in the determination of qualitative and quantitative MIC results. The appropriate dilutions of antifungal agents and colorimetric indicator were added to each well on the plate and results were determined by identifying the lowest antifungal concentration inhibiting growth.

\section{The isolation of the Clinical Samples}

The study included 50 Candida isolates collected from blood cultures of different patients and isolated with the BACTEC 9120 system (Becton-Dickinson, USA). After isolation in our laboratory, isolates were stored in stock medium at $-80{ }^{\circ} \mathrm{C}$, then dissolved in a refrigerator to $+4{ }^{\circ} \mathrm{C}$ and purified by two passages on Sabouraud Dextrose Agar (SDA) (Merck/Germany) medium. Then the growth Candida isolates were assessed according to the germ tube test, microscopic morphology on Corn Meal Agar with Tween-80 (Oxoid) agar and colony color on chromogenic medium and the species level was determined. The identification was supported using the API 20 C AUX system (bioMerieux, Marcy-l'Etoile, France).

\section{Antifungal Susceptibility Test}

The procedures were done according to the manufacturer's Sensititre YeastOne protocol. Candida isolates had a certain sample taken from 24 -hour pure cultures and suspensions were prepared in sterile water (T3339) and adjusted to 0.5 McFarland standards. To obtain $1.5-8 \times 103 \mathrm{kob} / \mathrm{ml}$ inoculum, $20 \mu \mathrm{l}$ suspension was transferred into $11 \mathrm{ml}$ YeastOne inoculum broth (Y3462).

Of the prepared suspension, $100 \mu \mathrm{l}$ samples were transferred to each well of a 96-well YeastOne plate and all the wells were covered with sterile adhesive band and left for incubation for 24 hours. To test the accuracy and purity of $0.5 \mathrm{McF}$ arland setting, a $10 \mu \mathrm{l}$ sample was taken from the positive control well on the inoculated plates and inoculated on SDA medium and panels incubated at $35^{\circ} \mathrm{C}$ for 24 to 48 hours in a non-CO2 incubator. Plates with growth of $10-80$ pure colonies were taken for assessment (5).

\section{The Assessment of the Test Results}

The plates were examined at the end of 24 hourincubation. Yeast growth was evident as a result of color change from blue (negative, no growth) to red (positive, growth) was observed. The positive control well on the plates was noted and if this well was completely red in color, the final values for the antifungals began to be read. The first well without color change (first blue) was determined as the MIC value (Figure 1). Plates with blue or faintly purple positive control wells were assessed as having weak growth and examined again after another 24 hours of incubation. Interpretation of MIC results was performed according to the CLSI criteria as recommended by the Sensititre YeastOne method (Table 1)(5).

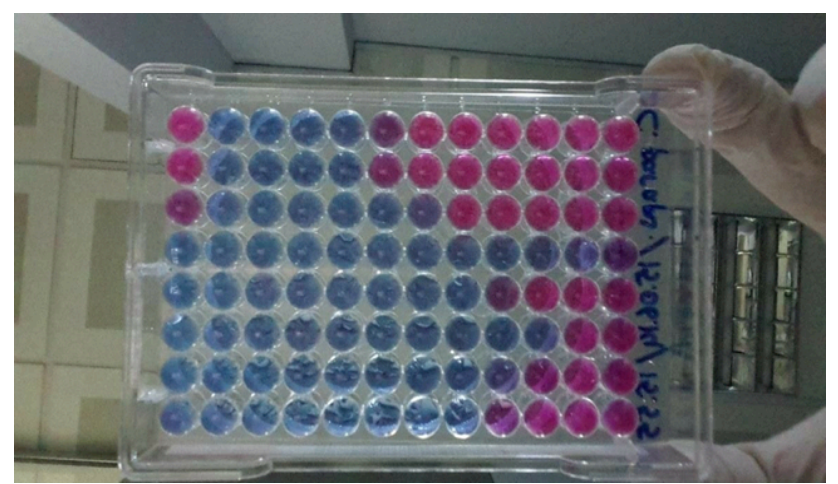

Figure 1. The appearance of the plates inoculated with yeast for 24 hours 
Table 1. MIC interpretative criteria for Candida species as per CLSI M27 ${ }^{5}$

\begin{tabular}{|l|c|c|c|c|}
\hline Antifungal Agent & Susceptible & Dose-dependent susceptible & Intermediate & Resistant \\
\hline Fluconazole & $\leq 8$ & $16-32$ & & $\geq 64$ \\
\hline Itraconazole & $\leq 0.125$ & $0.25-0.5$ & & $\geq 1$ \\
\hline Flucytosine & $\leq 4$ & & $8-16$ & $\geq 32$ \\
\hline Voriconazole & $\leq 1$ & 2 & & $\geq 4$ \\
\hline
\end{tabular}

${ }^{*}$ All units are microgram/milliliter

\section{RESULTS}

The wells with turbidity appearance on the plates after growth were not assessed. The wells without growth had no color change observed and in this situation the isolate was recorded as susceptible to the lowest concentration of the antifungal. For the wells with an observed color change, the isolate was recorded as greater than (>) the highest concentration of the antifungal. In one of the samples, contamination was observed on the SDA medium for purity and sterility control from the positive control well, and the strain was not included in the study. The number of colonies between 15-80 was counted after the breeding to test the number of colonies and the accuracy of the 0.5 McFarland setting was confirmed. All MIC values were in the expected range in plaques where quality control strains were tested(Table 2 ).

Table 2. MIC interval, MIC 50 and MIC 90 values for susceptibility identified with the microdilution method for Candida species

\begin{tabular}{|l|c|c|c|c|c|c|c|c|}
\hline & \multicolumn{2}{|c|}{ C. albicans $(\mathrm{n}=16)$} & \multicolumn{2}{c|}{ C. tropicalis $(\mathrm{n}=14)$} & \multicolumn{2}{c|}{ C. glabrata $(\mathrm{n}=10)$} & \multicolumn{2}{c|}{ C. parapsilosis (n=8) } \\
\hline Antifungal & $\begin{array}{c}\text { MIC } \\
\text { interval }\end{array}$ & $\begin{array}{c}\text { MIC } \\
50 / 90\end{array}$ & $\begin{array}{c}\text { MIC } \\
\text { interval }\end{array}$ & $\begin{array}{c}\text { MIC } \\
50 / 90\end{array}$ & $\begin{array}{c}\text { MIC } \\
\text { interval }\end{array}$ & $\begin{array}{c}\text { MIC } \\
50 / 90\end{array}$ & $\begin{array}{c}\text { MIC } \\
\text { interval }\end{array}$ & $\begin{array}{c}\text { MIC } \\
50 / 90\end{array}$ \\
\hline Anidulafungin & 0.015 & $0.015 / 0.12$ & $0.015-2$ & $0.03 / 1$ & $0.015-0.12$ & $0.06 / 0.06$ & $1-2$ & $1 / 2$ \\
\hline Micafungin & $0.008-1$ & $0.008 / 0.03$ & $0.015-1$ & $0.03 / 1$ & $0.015-0.5$ & $0.12 / 0.5$ & $0.5-2$ & $1 / 2$ \\
\hline Caspofungin & $0.015-0.5$ & $0.03 / 0.06$ & $0.015-0.5$ & $0.03 / 0.25$ & $0.015-0.5$ & $0.06 / 0.12$ & $0.25-0.5$ & $0.5 / 0.5$ \\
\hline Flucytosine & 0.06 & $0.06 / 0.06$ & $0.06-1$ & $0.06 / 0.25$ & $0.06-2$ & $0.5 / 1$ & $0.06-0.25$ & $0.12 / 0.25$ \\
\hline Posaconazole & $0.008-8$ & $0.015 / 0.03$ & $0.015-0.5$ & $0.025 / 0.5$ & $0.12-2$ & $0.12 / 0.5$ & $0.015-0.06$ & $0.03 / 0.03$ \\
\hline Voriconazole & $0.008-8$ & $0.008 / 0.008$ & $0.008-0.25$ & $0.12 / 0.25$ & $0.015-0.5$ & $0.03 / 0.06$ & $0.008-0.015$ & $0.008 / 0.015$ \\
\hline Itraconazole & $0.015-16$ & $0.015 / 0.06$ & $0.015-0.5$ & $0.25 / 0.5$ & $0.06-1$ & $0.12 / 0.25$ & $0.03-0.06$ & $0.06 / 0.06$ \\
\hline Fluconazole & $0.12-256$ & $0.25 / 0.5$ & $0.25-4$ & $2 / 4$ & $1-32$ & $2 / 4$ & $0,25-0.5$ & $0.5 / 0.5$ \\
\hline Amphotericin-B & $0.25-1$ & $0.5 / 1$ & $0.12-1$ & $0.5 / 1$ & $0.12-2$ & $0.5 / 1$ & 0.5 & $0.5 / 0.5$ \\
\hline
\end{tabular}

* All units are microgram/milliliter 


\section{DISCUSSION}

The most common risk factors for invasive candidiasis include major surgery, especially involving the abdomen, immunosuppression and supportive care measures used in the critically ill patients, such as long term broad spectrum antimicrobial therapy, central venous catheters, total parenteral nutrition, and renal replacement therapies. These factors explain, in part, the continuing high prevalence of Candida infections in transplant, cancer and intensive care units. Additionally in recent years, increased resistance to antifungal drugs has been a cause of concern in the treatment of the invasive fungal infections (6).

There are over 20 species of Candida yeasts that can cause infection in humans, the most common of which is C. albicans (7). Though C. albicans in the most common strain observed in both mucocutaneous and systemic infections, there is increasing incidence of non-albicans Candida species. The clinical findings of infections caused by non-albicans Candida strains cannot generally be differentiated and these strains are naturally resistant or gain resistance to commonly used antifungal drugs, as a result the definition of the species level of Candida isolates in clinical samples and the accurate and timely determination of in vitro susceptibility profiles are important for antifungal treatment protocols (8).

The CLSI broth microdilution method is still accepted as the gold standard for the assessment of susceptibility of Candida strains against antifungal agents. However, this method is expensive and difficult and challenges such as lack of expert personnel, new commercial systems with more practical and appropriate use. The most important problem with these systems is to ensure standardization of these new systems. Three commercial systems recommended for use include the E-test ( $\mathrm{AB}$ Biodisk Solna, Sweden), Sensititre YeastOne Colorimetric System (TREK Diagnostic Systems, USA) and VITEK 2
Yeast Susceptibility Test (BioMerieux, Inc, Durham, NC) $(9,10)$.

The Sensititre YeastOne method is based on the CLSI reference method and is stated to show high compliance with the CLSI method. It is a simple method for antifungal susceptibility tests in routine laboratory use. As it provides perfect results in terms of accuracy and repeatability compared to the CLSI reference method, it is commonly used in both clinical and research laboratories $(11,12)$.

Due to being easy to obtain commercially, the ability to test many antifungals at the same time and ease of application, the Sensititre YeastOne method was chosen in our study to show resistance limit values for Candida species against renewed fluconazole and caspofungin.

Gültekin et al. (13), used the Sensititre YeastOne system on 46 Candida isolates from blood cultures and identified that all strains were susceptible to amphotericin B, voriconazole, posaconazole and caspofungin. While the C. albicans, C. parapsilosis, C. glabrata and $C$. tropicalis strains were susceptible to fluconazole, three of the five $C$. glabrata isolates were identified to be resistant to itraconazole while other strains were susceptible to itraconazole.

In our study, C. albicans, C. parapsilosis, C. glabrata and $C$. tropicalis were susceptible to caspofungin and amp-B, with one $C$. albicans strain showing resistance to voriconazole. Fluconazole resistance was identified in one $C$. glabrata and one $C$. albicans strain. Itraconazole resistance was identified in one $C$. albicans and one $C$. glabrata strain, while one $C$. tropicalis strain was found to have dose-dependent susceptibility to itraconazole.

Three echinocandins (anidulafungin, caspofungin, and micafungin) have been licensed for intravenous treatment and prevention of invasive Candida infections (including candidemia). CLSI has established standard conditions for testing the susceptibilities of Candida spp. to the three echinocandins including species-specific breakpoints (BPs) for echinocandin 
MIC interpretation (14). The isolates we studied did not show any resistance to these antifungal drugs.

In our study, multiazol resistance was determined for isolate number eight of $C$. albicans strain. Additionally, this isolate was identified to have susceptibility of $>8 \mu \mathrm{g} / \mathrm{ml}$ posaconazole, $>8 \mu \mathrm{g} / \mathrm{ml}$ voriconazole, $>16 \mu \mathrm{g} / \mathrm{ml}$ itraconazole and $>256 \mu \mathrm{g} /$ $\mathrm{ml}$ fluconazole.

Cretella et al. (15), commercially available three antifungal susceptibility testing methods (Etest, Vitek 2 and Sensititre) were compared with the CLSI reference test method broth microdilution method and they reported the Sensititre YeastOne method was the system that provided closest results to the reference method.

In a study by Quindos et al. (16), reported the Sensititre YeastOne method showed perfect correlation with the E-test method. This correlation was better for voriconazole, with some incompatibility for fluconazole and C. glabrata.

A study conducted by Farina et al. (17), compared the Sensititre YeastOne method and VITEK 2 susceptibility system in seven different laboratories. They performed susceptibility tests for four different antifungals (amp-B, fluconazole, flucytosine and voriconazole) and reported that VITEK 2 susceptibility test system was more compliant compared to the Sensititre YeastOne. They observed the compliance between the two methods varied from $81.4 \%$ to $88.6 \%$.

Siqueira et al. (9), compared the susceptibility of 80 Candida isolates using the VITEK 2 and Sensititre YeastOne systems with the gold standard fluid dilution method. They concluded that both methods performed well and were reliable as antifungal susceptibility tests. However, they recommended careful interpretation when the activity of $C$. krusei and $C$. glabrata against caspofungin was tested with the Sensititre YeastOne method due to low observations.

Flusrand et al. (10), reported that Sensititre
YeastOne method showed good correlation with standard susceptibility tests for amphotericin B and triazoles, but that interpretation for echinocandins was more complicated (9).

A study by Avolio et al. (18), aimed to determine MIC values for yeasts as rapidly and accurately as possible. They compared values for 40 candidemia cases determined by the colorimetric Sensititre YeastOne system with the CLSI values. The results of the comparison found no major error, only four minor errors. The results of the study reported the Sensititre YeastOne colorimetric system accurate antifungal MIC determination and saving an average time of 24 hours compared with the time required for the standard procedures traditionally used.

In our study, there were small errors linked to inability to clearly determine the color change in the final wells, but these were not on a scale to change the susceptibility and resistance status.

The study by Bertout et al. (4), compared the Sensititre YeastOne commercial system with the CLSI reference broth microdilution test method. They studied two quality control strains and 102 Candida isolates with the antifungal agents, such as fluconazole, itraconazole, ketoconazole, posaconazole, voriconazole, flucytosine, Amp-B and caspofungin. They identified the compliance between the CLSI reference method and Sensititre YeastOne varied from $70.6 \%$ to $92.2 \%$.

In our study, for fluconazole there was dosedependent susceptibility for one Candida strain (MIC value $32 \mu \mathrm{g} / \mathrm{ml}$ ) and resistance identified in another Candida strain (MIC value $\geq 256 \mu \mathrm{g} / \mathrm{ml}$ ). The dosedependent susceptible strain was identified as $C$. glabrata, while the resistant strain was determined to be $C$. albicans. The MIC intervals for all Candida strains were determined as $0.12-2 \mu \mathrm{g} / \mathrm{ml}$ for Amp-B, 0.12-256 $\mu \mathrm{g} / \mathrm{ml}$ for fluconazole, $0.008-8 \mu \mathrm{g} / \mathrm{ml}$ for voriconazole, $0.015-0.5 \mu \mathrm{g} / \mathrm{ml}$ for caspofungin, $0.015-2 \mu \mathrm{g} / \mathrm{ml}$ for anidulafungin, $0.008-2 \mu \mathrm{g} / \mathrm{ml}$ for micafungin, $0.006-8 \mu \mathrm{g} / \mathrm{ml}$ for flucytosine, 0.008 - 
$8 \mu \mathrm{g} / \mathrm{ml}$ for posaconazole, and $0.015-16 \mu \mathrm{g} / \mathrm{ml}$ for itraconazole.

We think identification of resistance at different rates for all antifungal tests, and continuous strain identification and susceptibility studies in treatment of Candida infections will contribute to determining antifungal use protocols in our own hospital and will be beneficial to prepare comprehensive treatment protocols for the country in general. Additionally, we think the Sensititre antifungal susceptibility test is a useful method for being easy to obtain, simultaneous testing of nine antifungal agents and compliant results with the CLSI reference values.

Considering the low MIC values obtained, it was concluded that anidulafungin, micafungin, caspofungin, flucytosine, posaconazole, voriconazole, itraconazole and Amp-B can be effectively used against Candida strains, while they can be used as alternative drug for treatment of infections caused by strains resistant to fluconazole.

Note: This study was presented as a poster at the 10th Balkan Congress of Microbiology 2017 in Sofia, Bulgaria.

\section{REFERENCES}

1. Hancl SY, Derici YK, Sirin MC, Samlıoğlu P, Bayram A, Ağuș N. et al. Üçüncü basamak bir hastanede, geriatrik olgularda izóle edilen kandida türlerinin tiplendirilmesi ve kanda üreyen mayalarda antifungal duyarlıık. Dicle Med J, 2015; 42 (4): 438-44.

2. Atalay MA, Sav H, Demir G, Koç AN. Kan kültürlerinden izole edilen Candida türlerinin dağılımı ve amfoterisin B ve flukonazole in vitro duyarlılıkları. Selçuk Tıp Derg, 2012; 28(3): 149-51.

3. Hazırolan G. Albicans-dıșı Candida türlerinin flukonazol, itrakonazol, vorikonazole in vitro duyarlılığının referans Sıvı mikrodilüsyon yöntem ile araștırılması: yeni türe özgü klinik direnç sınır değerleri ve epidemiyolojik eșik değerlerinin uygulanması. Türk Mikrobiyol Cem Derg, 2018; 48(1): $38-44$.

4. Bertout S, Dunyach C, Drakulovski P, Reynes J, Mallie M. Comparison of the Sensititre YeastOne dilution method with the clinical laboratory standards institute (CLSI) M27-A3 microbroth dilution reference method for determining MIC of eight antifungal agents on 102 yeast strains. Pathol Biol, 2011; 59(1): 48-51.

5. Trek Diagnostic System. Sensititre search tool. www.trekds.com/techinfo. (Erișim tarihi: 24 Mart 2018).
6. Küçükates E, Gültekin NN, Alisan Z, Hondur N, Özturk R. Identification of Candida species and susceptibility testing with Sensititre YeastOne microdilution panel to 9 antifungal agents. Saudi Med J, 2016; 37(7): 750-7.

7. https://www.cdc.gov/fungal/diseases/ candidiasis/index.html. (Erișim tarihi: 04.04.2019).

8. Sav H, Demir G, Atalay MA, Koç AN. Aksu N. Klinik örneklerden izole edilen Candida türlerinin değerlendirilmesi. Turk Hij Den Biyol Derg, 2013; 70(4): $175-80$.

9. Siqueira RA, Doi AM, de Petrus Crossara PP, Koga PCM, Marques AG, Nunes FG, et al. Evaluation of two commercial methods for the susceptibility testing of Candida species: Vitek and Sensititre YeastOne. Rev Iberoam Micol, 2018; 35(2):83-7.

10. Furustrand Tafin U, Clauss M, Hauser PM, Bille J, Meis JF, Trampuz A. Isothermal microcalorimetry: a novel method for real-time determination of antifungal susceptibility of Aspergillus species. Clin. Microbiol. Infect, 2012; 18(7): 241-245.

11. Santhanam J, Yahaya N, Aziz MN. Species distribution and antifungal susceptibility patterns of Candida species: is low susceptibility to itraconazole a trend in Malaysia? Med J Malaysia, 2013; 68(4):343-7. 
12. Cantón E, Pemán J, Iñiguez C, Hervás D, LopezHontangas JL, Pina-Vaz C, et al. Epidemiological cutoff values for fluconazole, itraconazole, posaconazole, and voriconazole for six Candida species as determined by the colorimetric Sensititre YeastOne method. J Clin Microbiol, 2013; 51(8): 2691-5.

13. Gültekin B, Eyigör M, Tiryaki Y, Kırdar S, Aydın N. Kan kültürlerinden izole edilen Candida sușlarında antifungal duyarlılığın ve bazı virülans faktörlerinin araștırılması ve RAPD-PCR ile Genotiplendirilmesi. Mikrobiol Bul, 2011; 45(2):306-17.

14. Espinel-Ingroff A, Alvarez-Fernandez M, Cantón E, Carver PL, Chen SC-A, Eschenauer G, et al. Multicenter study of epidemiological cutoff values and detection of resistance in Candida spp. to anidulafungin, caspofungin and micafungin using the Sensititre YeastOne colorimetric method. Antimicrob Agents Chemother, 2015; 59(11): 672532.

15. Cretella D, Barbe KE, King ST, Stover KR. Comparison of susceptibility patterns using commercially available susceptibility testing methods performed on prevalent Candida spp. J Med Microbiol, 2016; 65(12): 1445-51.
16. Quindos G, Sanchez-Vargas LO, Villar-Vidal M, Eraso E, Alkorta M, Hernandez-Almaraz JL. Activities of fluconazole and voriconazole against bloodstream isolates of Candida glabrata and Candida krusei: a 14-year study in a Spanish tertiary medical centre. Int J Antimicrob Agents, 2008; 31(3): 266-71.

17. Farina C, Manso E, Andreoni S, Conte M, Fazii P, Lombardi G, et al. Interlaboratory evaluation of VITEK2 system and sensititre yeastOne for antifungal susceptibility testing of yeasts isolated from blood cultures against four antifungal agents. New Microbiol, 2011; 34(2): 195-201.

18. Avolio M, Grosso S, Bruschetta G, Rosa R.D. Camporese A. Direct antifungal susceptibility testing of positive Candida blood cultures by Sensititre YeastOne. New Microbiol, 2009; 32(2): 179-84. 